\title{
HIV / AIDS awareness among first year pharmacy students and the role of the university
}

\author{
S BEZUIDENHOUT AND RS SUMMERS
}

\begin{abstract}
As HIV/AIDS continues to spread and affect the lives of millions of people, a sense of urgency has developed about the imperative need to stop the epidemic. Education is the key to change knowledge, attitudes and behaviour. There is currently a gap in education programmes targeting youths of ages 18-24 years, for example, those enrolled in tertiary institutions. The aim of the study was therefore to establish the level of HIV/AIDS awareness among undergraduate pharmacy students at the University of Limpopo (Medunsa Campus)/Tshwane University of Technology Schools of Pharmacy. A structured questionnaire was administered to pharmacy students on entry to the programme. Although the students of 2003, 2004 and 2005 obtained mean percentage HIV/AIDS awareness scores in the range of $70 \%-80 \%$, they had inadequate knowledge of some transmission routes, events that occur when HIV invades the body, the "window period" and some symptoms. These knowledge gaps should be addressed by universities by integrating HIV/AIDS policies and education fully into all aspects of their planning, operations and teaching.
\end{abstract}

\section{Key words}

HIV/AIDS awareness; undergraduate students; Institutions of Higher Education

\section{Disciplines}

Medical studies, sociology, tertiary education.

Dr S (Selente)Bezuidenhout and Prof. RS (Rob) Summers are attached to the School of Pharmacy. University of Limpopo (Medunsa Campus). 


\section{Introduction}

During 2006, almost five million people became newly infected with human immunodeficiency virus (HIV), the greatest number in any single year since the beginning of the epidemic (UNAIDS/WHO, 2006). With no cure for HIV infection and a safe and effective vaccine several years away, the number of cases will increase well into the $21^{\text {st }}$ Century.

Young people continue to bear the brunt of the global HIV/AIDS epidemic. Those under the age of 25 account for more than half of all new HIV infections each year (UNAIDS, 2006). Those between the ages of 15 and 24 are particularly hard hit, especially girls and young women, who comprise the majority of young people living with the disease.

Surveys indicate that although young people have heard about the HIV/AIDS epidemic, awareness is not universal. Many of them are still unaware of how to protect themselves and/or they harbour misconceptions about HIV transmission (UNAIDS, 2006; UN, 2003).

Many sexually active young people at risk for HIV do not perceive themselves to be at risk. Moreover, most young HIV positive people do not know that they are infected. In addition, the prevalence of sexually transmitted infections in general among the youth is high, which increases the likelihood of acquiring or transmitting HIV (UN, 2003).

According to a report released by the South African Medical Research Council in November 2006 (Dorrington, R. et al. 2006), about 5.4 million out of a possible total South African population of 48 million are HIV positive. The country has more people living with HIV than any others except India. It is estimated that the probability of South Africa's 15-year-olds dying before they turn 60 increased from 29\% in 1996 to 56\% in 2006 (Dorrington, R. et al. 2006). Despite the fact that HIV prevalence among young people is high and rapidly rising there are few reliable data on HIV prevalence among students in South Africa's tertiary educational institutions.

A study at the University of Durban Westville (Stremlau, J. and Nkosi, $\mathrm{N}, 2001$ ), revealed infection rates of $26 \%$ in women and $12 \%$ in men aged 20 to 24 . There is no evidence, however, that these results were representative of all students at the university. In another institution, of the 1217 students who participated in a study carried out at the former Rand Afrikaans University (RAU) in 2001, 13 students tested HIV positive, a HIV prevalence rate of $1.1 \%$ (Uys, T. et al, 2001). 
This study also indicated that the students surveyed were generally knowledgeable about HIV and AIDS, although there were gaps in their knowledge relating to mother to child transmission (MTCT) and transmission from oral sex and related sexually transmitted infections (STIs).

According to Levine and Ross (Levine, S. and Ross, F, 2002), from the University of Cape Town (UCT), students' general knowledge of HIV/ AIDS transmission was good, with the exception of knowledge about vertical transmission. The latter finding is interesting, given that most respondents reported that the media had been instrumental in their obtaining a knowledge of the disease (The South African media give considerable attention to the prevention of mother to child transmission). In an investigation of oral contraceptives and condom use among 400 undergraduate students at the University of Limpopo (Medunsa Campus), $85 \%$ of the students stated that they had experienced sex previously. Most of these $(92 \%)$ stated that they were still sexually active (Mokobe, R. et al, 2006).

Evidence shows that when serious and sustained prevention efforts are targeted towards youths, it is possible for HIV rates to decline, e.g. after effective education campaigns HIV prevalence rates among pregnant girls aged 15 to 19 fell from 22 to seven percent in Uganda.

In Zambia, prevalence among 15 -19 year olds declined from 22 percent to 15 percent (www.unicef.org - 05-11-2006). It is suggested that the high level of knowledge about HIV/AIDS among Nigerian university students, as reported in a study by Aluede and colleagues in 2005 (Aluede, O, 2005), may be connected to the aggressive campaigns that have over the years been championed by relevant health and other institutions.

A review of UNAIDS publications not only showed that behaviour may be modified by HIV/AIDS and/or sex education, but that changes, when they do occur, are almost invariably in the desired direction (Grunseit, A and Aggleton, P, 1998). Hence, HIV prevention directed at youth is a crucial and effective strategy to alter the future course of the epidemic.

Education is a key to change knowledge, attitudes and behaviour. In Africa, HIV/AIDS is most prevalent within the 15-24 year old age group (Santis, W. et al, 2003). This cohort is thus the focus of many HIV/AIDS programmes. The majority of these programmes are, however, based at secondary school level. Although nearly all secondary schools in South Africa had implemented some form of life skills education in accordance with national policy, such education is not standardised. 
Coverage of the key topics varied and continues to vary considerably. Only motivated schools implemented the programme initially, while others elected to modify existing programmes. Furthermore, not all students attended life skills courses. In short, the extent to which life skills education is effective will depend upon a student's learning exposure, both in terms of duration and content (www.popcouncil.org/pdfs/horizons - 15-05-2005).

Hence, there appears to be a gap in targeting youths of ages 18-24 years, including those enrolled in tertiary educational institutions. Many arrive at the university already infected. Others will become infected whilst at university. Higher Education South Africa (HESA) acknowledges that 18-30 year olds are the age group with the highest risk of contracting the HI virus and therefore HIV/AIDS is of particular relevance in higher education (Cornelissen, 2005).

Education should ensure that students acquire knowledge and skills in order that they may adopt and maintain behaviour that will protect them from HIV infection. Van Wyk (2006) points out that not much research has been done at tertiary educational institutions on the perceptions and awareness of undergraduate students about the epidemic.

\section{Aim}

To establish the level of HIV and AIDS awareness/knowledge among first year pharmacy students at the Medunsa Campus School of Pharmacy, University of Limpopo.

\section{Method}

\section{Target population}

The target population was all first year pharmacy students from the University of Limpopo (Medunsa Campus)/Tshwane University of Technology Schools of Pharmacy in the years 2003, 2004 and 2005. The total population was included in the study to increase the reliability of the results.

The students completed an HIV/AIDS Awareness Questionnaire when they entered the pharmacy programme for their first year of study in the respective years. 


\section{Survey instrument}

A structured questionnaire (See Appendix 1) was designed and administered specifically for this study to determine the basic level of HIV/AIDS awareness of the students. The questionnaire was designed in the multiple-choice format. It consisted of the following sets of questions:

- Three questions on demographic characteristics (age, gender and race),

- Eleven HIV/AIDS awareness questions/statements which comprised a total of 27 items, each of which could be ticked as either correct or incorrect,

- Two open ended questions dealing with the cause and prevention of HIV/AIDS.

\section{Ethical approval}

Ethical approval for the study was obtained from the Medunsa Research, Ethics and Publications Committee.

\section{Analysis}

Students' HIV/AIDS awareness scores were measured as the percentage of correct responses out of the total possible mark of 27 .

Data from the completed HIV/AIDS Awareness Questionnaires were summarised by descriptive statistics. Demographic characteristics were summarised by frequency counts and percentages. The HIV/ AIDS awareness scores were summarised by sample sizes, means, standard deviations and minimum and maximum values.

\section{Results and Discussions}

\section{Overall results}

A total of 129 students completed the HIV/AIDS Awareness Questionnaire. The mean percentage awareness score was calculated for each group, on the basis of which the three groups were compared. No significant difference was found among the three groups $(p>0.05$, ANOVA) (See Table 1). 
Table 1: Awareness percentage scores of students in different years

\begin{tabular}{|l|l|l|l|l|l|l|l|}
\hline Group & $\begin{array}{l}\text { NuMBER OF } \\
\text { STUDENTS }\end{array}$ & $\begin{array}{l}\text { Response } \\
\text { RATE }\end{array}$ & $\begin{array}{l}\text { MEAN } \\
\text { ScORE }\end{array}$ & $\begin{array}{l}\text { StD } \\
\text { DeV }\end{array}$ & Min & MAX & $\begin{array}{l}\text { P-VALUE } \\
\text { (ANOVA) }\end{array}$ \\
\hline 2003 & 30 & $30(100 \%)$ & 78.0 & 16.7 & 29.6 & 96.3 & 0.583 \\
\hline 2004 & 47 & $46(98 \%)$ & 74.4 & 14.1 & 29.6 & 96.3 & \\
\hline 2005 & 52 & $51(98 \%)$ & 75.6 & 13.8 & 33.3 & 100.0 & \\
\hline OVERALL & 129 & $127(98 \%)$ & 75.6 & 14.6 & 29.6 & 100.0 & \\
\hline
\end{tabular}

\section{Results by Age}

The percentage HIV/AIDS awareness scores of all the students in the two age categories "younger than 20 years" and "20 years or older" were compared for least squares (LS) means (the expected value for a class or subclass mean that would be expected for a balanced design) to determine if there was a significant difference in their HIV/AIDS awareness scores. There was a statistically significant difference $(p=$ 0.05) in HIV/AIDS awareness between students younger than 20 years and students 20 years of age or older (See Table 2).

\section{Table 2: Awareness percentage scores by age: All students}

\begin{tabular}{|l|l|l|l|l|l|l|}
\hline $\begin{array}{l}\text { AGE } \\
\text { (YEARS) }\end{array}$ & NuMBER & $\begin{array}{l}\text { MEAN } \\
\text { ScorE }\end{array}$ & $\begin{array}{l}\text { STD } \\
\text { DEV }\end{array}$ & Min & MAX & LS MEAN \\
\hline$<20$ & 76 & 73.28 & 13.33 & 29.63 & 96.30 & 73.69 \\
\hline$\geq 20$ & 51 & 79.23 & 15.92 & 29.63 & 100.00 & 79.30 \\
\hline P-VALUE & $0.0416^{*}$ & & & & & \\
\hline
\end{tabular}

- Statistically significant

\section{Results by Gender}

The percentage HIV/AIDS awareness scores of all the male and female students were compared for LS means. The slight difference in HIV/ AIDS awareness between male and female students was not significant (See Table 3). 
Table 3: Awareness percentage scores by gender: All students

\begin{tabular}{|l|c|c|c|c|c|c|}
\hline GENDER & Number & $\begin{array}{c}\text { MEAN } \\
\text { Score }\end{array}$ & $\begin{array}{c}\text { STD } \\
\text { DEV }\end{array}$ & Min & MAX & LS MEAN \\
\hline FEMALE & 86 & 75.12 & 15.18 & 29.63 & 100.00 & 76.05 \\
\hline MALE & 41 & 76.87 & 13.65 & 33.33 & 96.30 & 76.93 \\
\hline P-VALUE & 0.7645 & & & & & \\
\hline
\end{tabular}

\section{Results by Race}

White, Asian and Coloured students were grouped together as "other races". Data for this group and the group of Black students (the majority) were compared for LS means. No significant difference in HIV/AIDS awareness was found between students from the different race group categories (See Table 4).

Table 4: Awareness percentage scores by race:

\section{All students}

\begin{tabular}{|l|l|l|l|l|l|l|}
\hline RACE & Number & $\begin{array}{c}\text { MEAN } \\
\text { ScORE }\end{array}$ & $\begin{array}{c}\text { StD } \\
\text { DEV }\end{array}$ & Min & MaX & LS MEAN \\
\hline BLACK & 95 & 75.81 & 14.66 & 29.63 & 100.00 & 76.72 \\
\hline OTHER & 32 & 75.35 & 14.92 & 40.74 & 96.30 & 76.27 \\
\hline P-VALUE & 0.8816 & & & & & \\
\hline
\end{tabular}

Table 5 reflects the percentage of students in each group (year) who responded with the correct answer to each of the 27 items in the HIV/AIDS Awareness Questionnaire. Pharmacy students' knowledge was considered adequate if $60 \%$ or more of the students provided the correct response.

This percentage was chosen because it indicates that a definite majority of the students had provided the correct responses. Percentages below $60 \%$ are highlighted in Table 5 . 


\section{Table 5: Percentage correct scores per question}

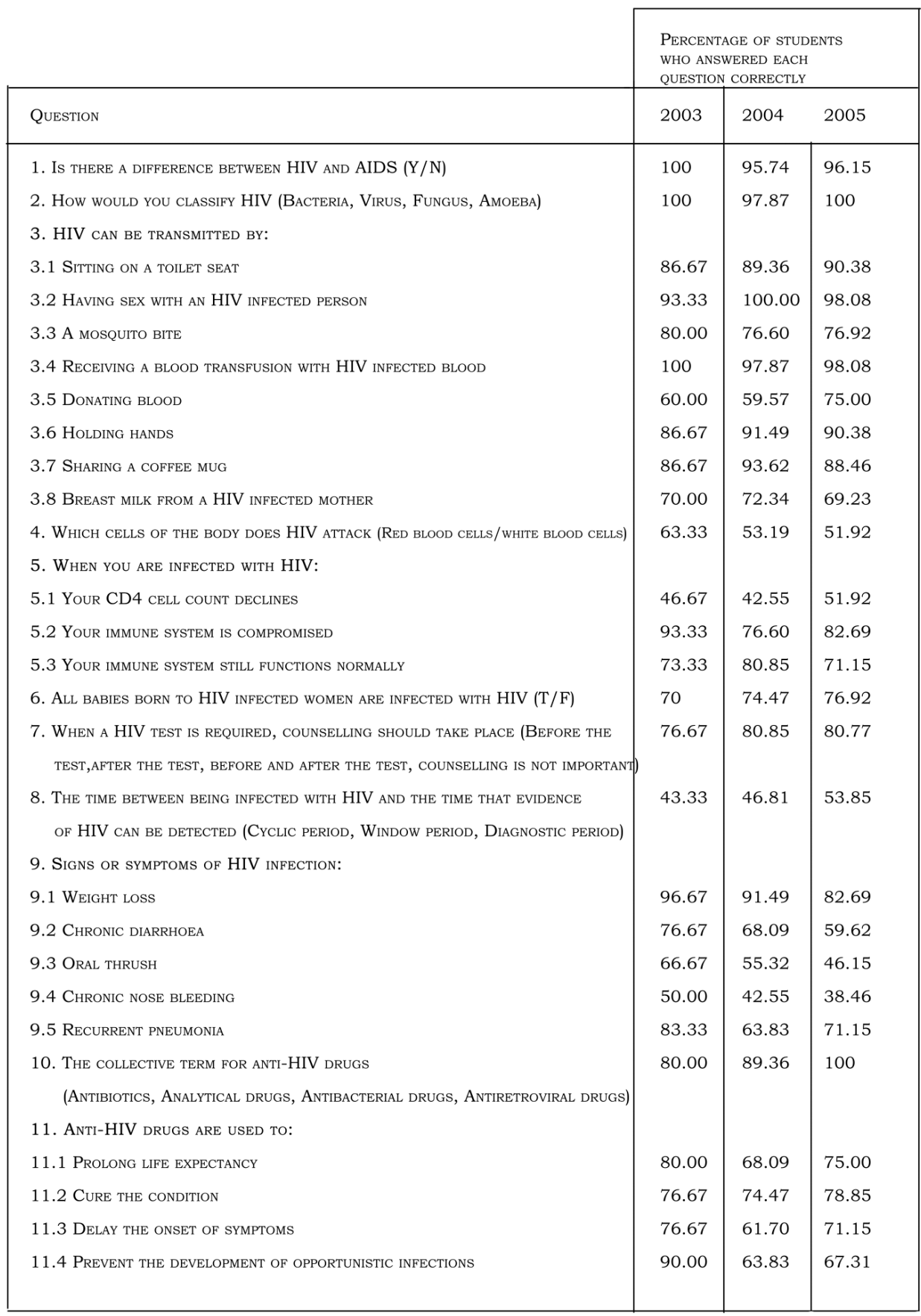


Table 5 illustrates that HIV/AIDS awareness was inadequate for questions $3.5,4,5.1,8,9.2,9.3$ and 9.4.

Marginal results were obtained for questions 3.5 and 9.2. However, the majority of students do not have sufficient knowledge regarding the pathology of HIV/AIDS (questions 4, 5.1 and 8). Students do not know that HIV attacks white blood cells and as the CD4 cell count declines, the immune system weakens.

The term "window period", although often used, is also unfamiliar to them. In question 9.4, the students wrongly identified chronic nose bleeding as a symptom of HIV/AIDS.

\section{Open-ended questions}

The questionnaire included two open-ended questions:

What do you think is the cause of AIDS?

How do you think HIV/AIDS can be prevented?

Responses from all the students are summarised in Table 6. The importance of HIV/AIDS information/education indicated by students as both "cause" and "prevention" is highlighted in grey.

\section{Table 6: Responses to open-ended questions}

\begin{tabular}{|c|c|c|c|}
\hline $\begin{array}{l}\text { THE CAUSE OF } \\
\text { AIDS }(\mathrm{N}=124)\end{array}$ & REsPONSE & $\begin{array}{l}\text { PREVENTION OF } \\
\text { HIV / AIDS }(\mathrm{N}=127)\end{array}$ & RESPONSE \\
\hline HIV & $43(34.67 \%)$ & ABSTAINING FROM SEX & $48(37.79 \%)$ \\
\hline UNPROTECTED SEX & $37(29.83 \%)$ & PRACTISE SAFE SEX & $47(37.00 \%)$ \\
\hline PROMISCUITY & $14(11.29 \%)$ & NEED MORE EDUCATION AND INFORMATION & $15(11.81 \%)$ \\
\hline IMMUNE SYSTEM NOT FUNCTIONING & $11(8.87 \%)$ & No PROMISCUITY & $11(8.66 \%)$ \\
\hline NOT ENOUGH EDUCATION AND INFORMATION & $4(3.22 \%)$ & NEED MORE HIV/AIDS AWARENESS & $5(3.93 \%)$ \\
\hline NO IDEA & $4(3.22 \%)$ & PEOPLE MUST STOP IGNORING THE VIRUS & $1(0.78 \%)$ \\
\hline VIRUS ATTACKING THE IMMUNE SYSTEM & $3(2.41 \%)$ & & \\
\hline OTHER * & $8(6.45 \%)$ & & \\
\hline
\end{tabular}

TD, 3(2), December 2007, pp. 305-318 
* Include no exercise (1), scientifically not known (1), sex with a monkey (1), insects (1), man-made disease (1), people living against the laws of nature (1), human blood infected by blood from a green monkey (1) and STIs (1) .

From the responses to the open-ended questions it is evident that many students are not familiar with the cause of AIDS. Only $34.67 \%$ of them correctly indicated HIV as the cause of AIDS. Less than $40 \%$ of them indicated that abstaining from sex and practising safe sex are the best methods of prevention.

\section{Conclusion and reccommendations}

The significant findings of this study therefore include the following points:

1. Older students know more about HIV/AIDS than younger ones.

2. Poor awareness of the pathology of the condition exists.

3. Some symptoms are not well known.

4. There is a link between "lack of education" as a stated cause of HIV and "more education" as a need to contribute to the prevention of HIV infection.

The data obtained in this study correspond with those found in studies conducted where HIV/AIDS knowledge of university students was found to be high, although misconceptions occurred regarding transmission of the virus (Friedland, R. et al, 1991; Harding, A. et al, 1999; Kelly, M. 2001).

Fifteen percent of our respondents incorrectly identified mosquito bites and double that percentage identified donating blood as methods of viral transmission.

The fact that younger students know less about HIV/AIDS can possibly be attributed to the inadequacy of school programmes to educate learners, as mentioned previously. Also, one of the main issues that have hindered the implementation of HIV/AIDS prevention programmes is the lack of teacher training. Due to the lack of training, teachers are unable to master the basic information about HIV/AIDS, thus making it impossible to practise and become confident enough to educate their students effectively. HIV/AIDS needs to be 
understood and taught in its entirety. If it is not possible to explain to children how HIV/AIDS is contracted and prevented it drastically reduces the effectiveness of HIV/AIDS education.

Another issue that teachers are faced with is the culture of silence surrounding the disease. The fact remains that teachers are still too afraid to address issues such as HIV/AIDS and sex education as they are unsure whether it is their responsibility or that of the parent (Griffiths, 2005). The "S" factors - shame, silence and stigma - are among the basic reasons behind continued HIV/AIDS fears leading to denial, blame and discrimination, thereby delaying positive action. Teachers must recognise these factors in their community in order to be able to address them in class.

A third factor that plays a role is teacher absenteeism rates. Up to 12 percent of teachers in South Africa are HIV/AIDS positive. Losing teachers in high numbers greatly reduces the capacity of the school system to provide education. Therefore, without enough teachers to effectively implement HIV/AIDS programmes, programmes continue to struggle and children continue to suffer (Griffiths, 2005).

Education is still a key to change knowledge and attitudes. Universities must play a major role in this regard. According to the Higher Education HIV/AIDS Programme all higher education institutions in South Africa should incorporate HIV and AIDS content into their curricula with the necessary scope and depth. The programme envisions that graduates should be competent in HIV and AIDS issues (HEAIDS Programme Report, 2005). However, not all universities are committed in the fight against HIV/AIDS.

Although university departments are carrying out research about the disease, they are also morally bound to produce graduates equipped to manage the pandemic, help prevent infection among students and staff and accommodate those who are infected. Several universities have really good HIV/AIDS policies, but are, as yet, unable to back them up with any more than a few limited initiatives (MacGregor, K, 2001). Although different departments are carrying out research, projects are often unconnected with each other, due to the lack of coordination across faculty and departmental barriers.

In our case, despite the existence of the Centre for Vaccine Research and the offering of a Post Graduate Diploma in HIV/AIDS Management on the Medunsa Campus, there is an unofficial, personal and institutional silence about HIV/AIDS. For example, there is an unknown number of staff and students living with HIV/AIDS on campus. Unknown, because there are no baseline scientific data available of the prevalence of HIV/AIDS, as no studies have been performed. Hence, there is a need for information on the extent of the problem at the university. 
Condoms are only distributed occasionally, awareness campaigns are limited, there is no on campus VCT service, and training for staff, especially non-academic, is not provided (Higher Education HIV/ AIDS Programme, 2004). While students are at least cautioned regarding the risks of student life, no similar orientation is available to staff members, nor is there an ongoing programme that deals with AIDS-related issues for staff members. After two years the HIV/AIDS policy is still in draft form.

Universities must survive the epidemic in terms of enrolments, funding and economics. If members of the Medunsa Campus community share their expertise, resources and experiences with each other, and there is a commitment from the top to a comprehensive education campaign, it should be possible to develop a powerful, integrated university-wide contribution to combating the epidemic.

These suggestions are in line with the critical areas identified for action by the Higher Education HIV / AIDS Programme (HEAIDS). They were: (1) Effective policy, leadership and management; (2) Appropriate research/knowledge production; (3) Effective prevention; (4) Effective treatment, care and support; (5) Teaching appropriate within an HIV/ AIDS context and (6) Community outreach (HEAIDS-strategic framework 2006-2009).

In view of the fact that not much research has been done in the area of HIV/AIDS knowledge in the tertiary sector of education it is important that future research must include HIV/AIDS awareness studies among all students and staff, determination of HIV/AIDS prevalence on campus, the development of HIV/AIDS workplace programmes and active awareness campaigns. HEAIDS are currently advertising for project tenders for the design and implementation of comprehensive HIV/AIDS workplace programmes benefiting academic, administrative and support staff at all HEIs in South Africa.

However, responses to HIV/AIDS should not be driven by individuals and small groups only, or by external organisations, but by universities as a whole through the appointment of full-time campus HIV/AIDS Co-ordinator/managers. Effective responses can only be achieved in an environment that is characterised by visionary leadership and good governance. 


\section{References}

Aluede, O; Imhonde, H; Maliki, A. \& Alutu,N. 2005. Assessing Nigerian University students' knowledge about HIV/AIDS. J. Soc. Sci, 11(3): 207-213.

Cornelissen, M. 2005. HIV/AIDS knowledge, awareness and perception of undergraduate students at the University of Stellenbosch. Assignment presented in partial fulfilment for the degree of Master of Philosophy at Stellenbosch University.

Dorrington, R; Johnson, L; Bradshaw, D. \& Daniel, T. 2006. The demographic impact of HIV/AIDS in South Africa. National and Provincial indicators for 2006. Cape Town: Centre for Actuarial Research, South African Medical Research Council and Actuarial Society of South Africa.

Friedland, R; Jankelowitz, S; de Beer, M; de Klerk, C; Khoury, V; Csizmadia, T; Padayachee, G. \& Levy, S. 1991. Perceptions and knowledge about the acquired immunodeficiency syndrome among students in university residences. S Afr Med J, 79(3): $149-154$.

Grunseit, A and Aggleton, P. 1998. Lessons learned: an update on the published literature concerning the impact of HIV and sexuality education for young people. Health Education. Number 2, March: 45-54.

Harding, K; Anadu, E; Gray, L. \& Champeau, D. 1999. Nigerian university students' knowledge, perceptions and behaviours about HIV/AIDS: are these students at risk? Journal of Social Health. 119(1):23-31.

Higher Education HIV/AIDS Programme. 2004. HIV and AIDS: Interventions in South African Higher Education.

Higher Education HIV/AIDS - strategic framework 2006-2009 and beyond. Available from www.hesa.org.za

Kelly, M. 2001. Challenging the challenger: understanding and expanding the response of universities in Africa to HIV/AIDS. Washington: ADEA Working Group on Higher Education, World Bank.

Levine, S. \& Ross, F. 2002. Perceptions of and attitudes to HIV/AIDS among young adults at the University of Cape Town. CSSR Working Paper No 14.

MacGregor, K. 2001. Universities fight South Africa's AIDS crisis. Available from www.chet.org.za/issues/ 
universitiesfightaids.doc

Mokobe, R; Tsime, W., Masinga, G. \& Meyer JC. An investigation of the use of oral contraceptives and condoms by undergraduate Medunsa students. $20^{\text {th }}$ Annual Conference of the SA Association of Hospital and Institutional Pharmacists, Wilderness, 2006.

Santis, W; Whitman, C; Venkatapuram, S; Rosenblum, M; Rosati, M. \& Palakurti, P. 2003. HIV/AIDS and employment: Protecting young people and involving them in work-related solutions. Available from www.hhd.org/documents/hyderabad.pdf

Stremlau, J. \& Nkosi, N. 2001. The AIDS crisis at South African Universities. Available from www.idrc.ca/en/ev-5398-201-1DO_TOPIC.html

Transitions to adulthood in the context of AIDS IN South Africa: The impact of exposure to life skills education on adolescent, knowledge,skills and behaviour. Available from www.popcouncil.org/pdfs/horizons/lfsklsfnl.pdf - Accessed 1506-2005

UN. World Youth Report 2003. The global situation of young people

UNAIDS. 2006. Report on the Global AIDS Epidemic.

UNAIDS/WHO. 2006. AIDS epidemic update. December 2006.

UNICEF. HIV/AIDS and children: How does HIV affect young people? Available from www.unicef.org/aids/index_youngpeople.html

Uys, T; Ichharam, M; Martin, L. \& Alexander, P. 2001. HIV/AIDS and students at RAU. Interim Report.

Van Wyk, C. 2006. HIV/AIDS perceptions, attitudes and awareness of undergraduate students. The Journal of Transdisciplinary Research in South Africa. 2(1): 165-180. 